\title{
Sacred islands and island symbolism in Ancient and Imperial China: an exercise in decolonial island studies
}

\author{
Bin Luo \\ Sun Yat-sen University, Guangzhou, China \\ robinluol210@126.com
}

and

\author{
Adam Grydehøj \\ Ilisimatusarfik/University of Greenland, Nuuk, Greenland \\ Island Dynamics, Copenhagen, Denmark \\ agrydehoj@islanddynamics.org
}

\begin{abstract}
This paper explores conceptions of islands in Ancient and Imperial China. From at least the 3rd Century BCE, mainland Chinese culture regarded islands as sacred, unapproachable fairylands, home to the elixir of immortality. This inspired a trend for voyages in search of mythological sacred islands as well as a landscape architecture trend for constructing artificial islands in imperial palace gardens. Over time, Taoism came to associate islands with the home of the gods, and Chinese Buddhism came to associate islands with dragon kings. As China's maritime activity increased, so, too, did fiction regarding islands of adventure. These conceptions of sacred islands and islands of adventure coexisted with the use of actual islands as places of political exile. By exploring island traditions in Chinese literature, this paper adds to our knowledge of how and why people throughout history have regarded islands and archipelagos as special. This paper also pursues a decolonial island studies by challenging some of the Eurocentric and imperialistic tendencies within the research field, which have led to a privileging of Western island metaphors and understandings.
\end{abstract}

Keywords: Ancient China, Chinese literature, decolonial island studies, Imperial China, landscape architecture, sacred islands

https://doi.org/10.24043/isj.19

(C) 2017 - Institute of Island Studies, University of Prince Edward Island, Canada.

Introduction: islands outside the West

The influential Chinese-American geographer Yi-Fu Tuan (1974, p. 118) states that "The island seems to have a tenacious hold on the human imagination [...]. But it is in the imagination of the Western world that the island has taken the strongest hold." Like Tuan, John Gillis (2007, p. 274) identifies something peculiarly Western in the fascination with islands: "The chimerical character of islands is not just a product of physical conditions. It is equally a result of culture-Western mainland culture, to be specific-which has attributed to islands certain wondrous features that it rarely bestows on other landforms." Indeed, the 'island lure' (Baldacchino, 2012b) and the outsized role that islands (both real and metaphorical) play in Western culture has been a focus of scholarship within the field of island studies.

In the present article, we argue that although Western mainland culture has produced a particular image of islands, the important cultural role of this landform is not limited to and does not originate from Western mainland culture. Specifically, there are strong correlations between historical Western 
and historical Chinese representations and cultural uses of islands, to such an extent that it seems clear that it is not just the mainland that casts particular dreams upon islands but also islands that exert particular influences on the mainland imagination. As such, the Western focus of much current island studies theorisation means we risk missing out on or misunderstanding key aspects of islandness in the cultural imagination. By ignoring islands and conceptions of islands in certain geographical regions (in part due to a lack of English-language scholarship), the international island studies community has been engaging in "overly broad deductive practices" (Grydehøj, 2017, p. 8) and unintentionally privileging Western epistemologies. Besides challenging a number of existing theories that have developed as to why islands represent special geographical forms, we illustrate how knowledge of non-Western conceptions of islands can add depth to island studies. Considerable work has already been done to consider islands from a postcolonial or decolonial perspectivethough often without critically interrogating how the ideas concerning islands held by the coloniser and the colonised have influenced one another. China is not the only land to have produced non-Western conceptualisations of islands and islandness, and we hope that the present investigation will inspire further attempts to explore other non-Western traditions of islands.

A number of Indigenous scholars (e.g., Hau'ofa, 1994; Gegeo, 2001; Teaiwa, 2006) have sought to draw Indigenous island epistemologies out from the shadows of coloniality. The present paper pursues "decolonial island studies" (Nadarajah \& Grydehøj, 2016), not in the sense that it grapples directly with issues of coloniality but instead in the sense that it presents a "decolonial option” (Mignolo, 2011) for understanding islandness.

It is not a law of nature that scholars must continually interpret, conceptualise, and theorise the islands of China, Oceania, the India Ocean, and even Europe itself with reference to touchstones of Western culture: Homer's Odyssey, More's Utopia, Shakespeare's The Tempest, Defoe's Robinson Crusoe. These and other classic works of Western literature have, of course, been drawn upon and turned back toward the West by countless decolonial authors outside the West. Nevertheless, there is more than just a whiff of lingering imperialism in the scholarly drive to use Western representations of non-Western characters and landscapes as a means of giving meaning to the non-Western world. It is a product of imperialism that even many of the most enlightened and well-intentioned scholars can regard it as legitimate to apply Western island metaphors as a universal standard, irrespective of the endemic, alternative island understandings that may be in place locally. Pete Hay (2006, p. 28) highlights how "The [metaphorical] island itself is seen to be a post-colonial trope, one traceable to Eurocentric assumptions of dominance," yet such a statement itself neglects the possibility that those outside the West-islanders and mainlanders alike-have constructed their own metaphors of islandness with which to imbue physical island places.

We do not seek to criticise attentiveness to the role of islands within Western culture; we simply note that inattentiveness to non-Western ways of seeing, thinking about, and practicing islandness perpetuates processes of domination and marginalisation. As we show, despite arising in isolation from one another, mainland European and Chinese traditions of islands have much in common. A fascination with islands is specifically not an innovation that the West introduced to the rest of the world, yet this is scarcely reflected in many of the most important scholarly efforts to theorise islandness.

We proceed with a brief overview of important discussions taking place in the international (largely Westernised) island studies community today. We then describe and analyse representations of islands in Ancient and Imperial Chinese historical, religious, and geographical texts as well as works of fiction. Ancient China is conventionally dated as ending after the Warring States Period (476-221 $\mathrm{BCE}$ ), while Imperial China is conventionally dated as stretching from the start of the Qin Dynasty (221 BCE) to the end of the Qing Dynasty (1911 CE). This paper considers the depiction of islands as sacred places, the production of artificial islands in landscape architecture, the role of islands in Taoism and Chinese Buddhism, narratives of dangerous islands in the age of maritime exploration, and islands as places of exile. These descriptions and analyses are accompanied by comparisons with Classical, Medieval, and Early Modern European representations of islands.

All translations from Chinese to English have been made by Bin Luo unless otherwise noted. 


\section{Current trends in international island studies}

Island studies is a complex field with a complex history (Baldacchino, 2004), to which it would be impossible to do justice in just a few paragraphs. However, in order to set into perspective the subsequent discussions of Ancient and Imperial Chinese conceptions of islands, we briefly sketch out a number of significant ongoing discussions in international island studies. Because this paper focuses primarily on how mainlanders conceive of islands, we emphasise (predominantly Western) theories concerning physical or conceptual interactions between islands and mainlands.

A key point of contention within the field has revolved around the definition of the 'island' itself and the appropriate subject matter of island studies. Hay (2006, p. 30), recognising the metaphorical and symbolic prominence of islands within Western culture, nevertheless argues against the study of island metaphors within island studies (also known as 'nissology'):

Island metaphors not only wrongly represent the politics of island identity as conservative, then; they also render irrelevant the realness of island lives. Such metaphors were not, after all, generated by islanders. They are continental, as well as colonial, constructions. [...] I do not believe that they fit within the purview of nissological investigation, which should, rather, concern itself with the reality of islands and how it is for islands and islanders in the times that are here and that are emerging.

As Godfrey Baldacchino (2008) has noted, however, mainlanders and islanders co-construct island metaphors and ideas regarding islandness, even if they may have different reasons for and methods of doing so, and even if such metaphors prove problematic for people who dwell on islands. The tension between island as metaphor and island as place has thus formed the crux of much powerful island studies theorisation, engaged in from different perspectives and arriving at different conclusions (e.g., Fletcher, 2011; Ronström, 2013; Pigou-Dennis \& Grydehøj, 2014; Hong, 2017).

Elaine Stratford et al. (2011) seek to circumvent some of island studies' essentialising tendencies by complementing research into island/mainland and land/sea binaries with an appreciation of island-island relationships, by 'envisioning the archipelago'. Jonathan Pugh (2013) has advanced this line of theorisation by pursuing a spatially sensitive, fluid, relational approach to archipelagos. As Pugh (2016, p. 1053) argues, it is possible to be cognisant of the attributes and distinctiveness of islands as places without denying "complex and shifting island, sea and ship relations." Philip Hayward (2012a, 2012b) has used the concepts of the 'aquapelago' and the 'aquapelagic assemblage' to explore land-sea-human interaction, thereby offering a new means of conceptualising what it means to be an islander and to engage with islands.

The emergence of a distinctive form of urban island studies over the past few years has, for its part, both thrown doubt upon certain marginalising island metaphors and clichés and emphasised the symbolic power of islandness when applied to physical islands. Adam Grydehøj (2015a, 2015b) has demonstrated that island and archipelago spatiality have a strong effect on urbanisation processes and that, under certain geographical conditions, such spatiality can foster the development of very dense and very large cities. Other scholars have used the concept of island cities as a means of understanding the effects of islandness in urban environments, of seeing how the 'island lure' functions even in centres of economic, political, and cultural power (e.g., Swaminathan, 2015; Steyn, 2015; Casagrande, 2016; Su, 2017).

We shall engage with these and other currents of contemporary Western island theory in the following discussion of the cultural significance of islands in Ancient and Imperial China.

\section{Mountains in the sea}

Relative to the Western European experience, the transition from Chinese prehistory to Chinese history occurred at a very early date. Written inscriptions and other archaeological evidence 
complement later historical writing in attesting to the existence of complex state and societal formations in the Yellow River basin from the mid- $2^{\text {nd }}$ Millennia BCE. At this time, most of the population of what we now regard as China resided in the north of the country, far from the ocean and sea, and, for most of the next 3500 years, China's centres of political and economic power were located in the continental interior. As a result, China developed a mainland-centred culture (Hong, 2017), and Chinese social, political, and religious actors tended to focus on land power.

Nevertheless, China's coastal waters contain thousands of islands, and islands have long been significant in the Chinese imagination. Narratives of islands go back over two millennia, to the very earliest extant Chinese literature. Although some of the island conceptions we discuss in this paper no doubt go further back than extant written sources attest, we confine ourselves here to working with the writings that still exist.

The Chinese writing system was among the earliest in the world. It had developed over a number of millennia in the Yellow River basin, taking on a standardised form over the course of the Qin and Han Dynasties (221 BCE-220 CE). The general Chinese word for 'island' is dao 岛 (the traditional form is 島). 岛 can be divided into two constituent characters, 鸟 (bird) and 山 (mountain). The 2nd-Century CE Chinese dictionary Explaining Graphs 说文 defines 岛 as follows: "Island is the mountain in the sea that could be stopped over at [by birds]" (qtd. in 曹先擢，苏培成, 1999, p. 99). There is a general association between islands and mountains, not just in Qin and Han Dynasty texts but also in place names, so that, for example, the name of China's largest offshore archipelago is Zhoushan 舟山 ('Boat Mountain'). Islands were furthermore regarded from the earliest written records as 'heavenly mountains' 仙山 or 'fairylands' 仙境 that were home to spirits, gods, goddesses, or immortals 仙人.

It is interesting to compare 岛 with the terms for 'island' that developed in European languages. The general terms for 'island' in English, German, and the Scandinavian languages have common (proto-)Indo-European origins that denote water and-by extension-things located in or near water. As a result, today's primary Scandinavian word for stream/river (a) has the same origins as the Scandinavian word for island (ö/ø) (Ronström, 2009, pp. 166-167). Within the European languages more generally, Ronström (2009, p. 170) finds, the relationship between land and water tends to be central to the words for islands, even when these words do not possess common roots.

There thus seems to be a shared and ancient European island imaginary in which water is the essence of the island. This differs fundamentally from Chinese, in which the mountain is the essence of the island-not because China's islands are particularly mountainous relative to European islands or relative to mainland China but perhaps because, for a civilisation that arose and developed far from the coasts, the mountain proved to be a stronger overarching metaphor and symbol than in Europe. It is therefore particularly intriguing that Chinese culture came to ascribe similar kinds of significance to mountains and to islands and that these ascriptions closely match contemporary and later European ideas concerning islands.

\section{Searching for and constructing sacred islands}

The three most famous islands in Qin and Han Dynasty literary works are Penglai 蓬莱, Fangzhang 方丈, and Yingzhou 瀛洲, which were regarded as real, existing islands yet simultaneously symbolised heaven or fairyland. Reports of these three sacred islands first appear in the 2nd- and 1st-Century BCE Records of the Grand Historian's (史记) 'The Sacrificial Ceremony Section':

King Wei, King Xuan of Qi State, and King Zhao of Yan State sent people to look for the three sacred islands, namely, Penglai, Fangzhang, and Yingzhou. The three sacred islands were said to be in the Bohai Sea, not far from the habitat of humans. When people approached, a disastrous wind would hit and force the boat to leave. Those who landed on the islands saw gods and goddesses, and found elixir [food of the gods] on the 
islands. The animals and things on the islands are all white. The palaces are made of gold and silver. Seen from afar, the islands are swathed in clouds. Before arrival, the three islands exist below the water. When someone wishes to land, the wind comes and arrival becomes impossible (史记・封禅书, pp. 1369-1370).

These three islands are described as exemplary sacred places: white symbolises purity and holiness, and gold and silver palaces symbolise great wealth and carefree living. Although the islands are sacred and spectacular, they are also shrouded in mystery and can never be reached by humans. They are covered by mist, and the men sent by the kings do not succeed in landing on them.

The report just quoted was written centuries after the fact. However, the search for the three sacred islands continued and was further developed in the Qin Dynasty (221 BCE-207 BCE), that is, shortly before its recording in 'A Record of the First Emperor, Qin Shihuang' in Records of the Grand Historian:

Xushi from Qi State, together with others, told the Emperor that there were three islands in the ocean, namely Penglai, Fangzhang, and Yingzhou, where gods and goddesses live. Xushi requested a sacred island search after a sacrificial fast and bath. He suggested that the search team be comprised of virgin young men and women. The Emperor then granted him permission to select the virgin young men and women, and then Xushi began the holy search (史记・秦始皇本纪, p. 237).

Although these descriptions of quests for the three sacred islands may sound like the stuff of legend, the court official Xushi (徐市, also known as Xufu (徐福)) truly did set out in search of the islands on two separate occasions, in 219 and 210 BCE, at the behest of Emperor Qin Shihuang (秦始皇). Records of the Grand Historian mentions Xushi’s quest over ten times.

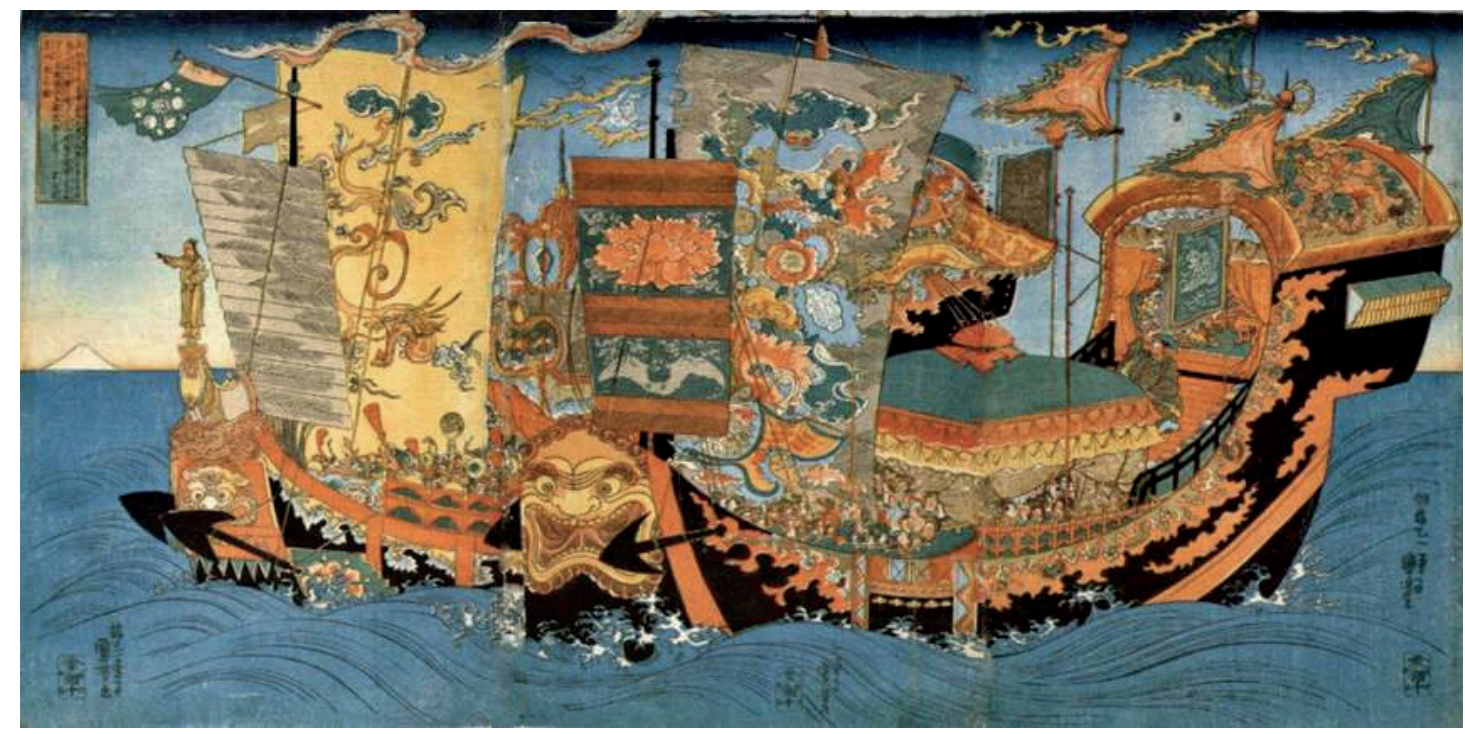

Figure 1: Mid-19th Century illustration of Xushi's 219 BCE quest for the sacred islands, by the Japanese artist Utagawa Kuniyoshi. (Source: Wikimedia Commons, https://commons.wikimedia.org/wiki/File:Xu Fu expedition\%27s for the elixir of life.jpg)

Records of the Grand Historian's 'Sacrificial Ceremony Section' mentions another sacred island and elixir quest. Emperor Wu-ti (156 BCE-87 BCE) of the Han Dynasty (206 BCE-220 CE) initiated a journey in search of elixir. Li Shaojun 李少君, a well-known fangshi 方士 (alchemist/sorcerer) told Wu-ti that he had: 
travelled to the seas and saw An Qisheng. An was eating a kind of jujube, which was as big as a watermelon. An Qisheng, going back and forth between Penglai Mountain, only met those who are predestined. If someone who was not predestined wanted to meet, he would just hide. Then, the Emperor started to offer sacrifices to the kitchen god and later sent alchemists to look for An Qisheng and other gods in the sea (史记・封禅书, p. 1385).

An Qisheng is evidently an immortal living on the island. The 'predestined' are those who are capable of receiving An's help and who may consume elixir. Wu-ti later organised several other major searches for the sacred islands, ultimately taking place over many years and involving large numbers of people (孟天运, 2000). Wu-ti's objective was not territorial acquisition but instead elixir, which rulers of various Imperial Chinese dynasties sought to obtain.

The three sacred islands were believed to exist on or beyond the periphery of China, but attempts were made already in the 3rd Century BCE to bring them to the centre of Chinese power by recreating them in garden design and landscape architecture. Emperor Qin Shihuang, who had ordered Xushi's voyages, had lakes and hills (including imitations of the Penglai and Yingzhou) constructed within the walls of Epang Palace 阿房宫 to reinforce the theme of immortality (Yao, 2016, pp. 74-75; 顾炎武, 1984, p. 43). According to Records of the Grand Historian, "Emperor Wu-ti of the Han Dynasty built Jianzhang Palace, Ganquan Palace, and Taiye Lake. Penglai, Fangzhang, and Yingzhou islands are inside Taiye Lake and resemble the sacred islands in the ocean" (史记・孝武本纪, p. 482). In the $3^{\text {rd }}$ and $2^{\text {nd }}$ Centuries BCE, Emperors Qin Shihuang and Wu-ti thus both ordered quests for sacred islands and had these islands reproduced in palace gardens.

The practice of building artificial lakes and sacred islands was continuing over seven hundred years later. Comprehensive Mirror in Aid of Governance 资治通鉴 records that the Sui Dynasty (581-618 CE) imperial palace of Xiyuan 西苑 in Luoyang “has a perimeter of 60,000 $\mathrm{m}^{2}$, inside which the water takes up a perimeter of $5000 \mathrm{~m}^{2}$. Penglai, Fangzhang, and Yingzhou, with a height of over $30 \mathrm{~m}$, are built in the water" (司马光, 1976, p. 5620).

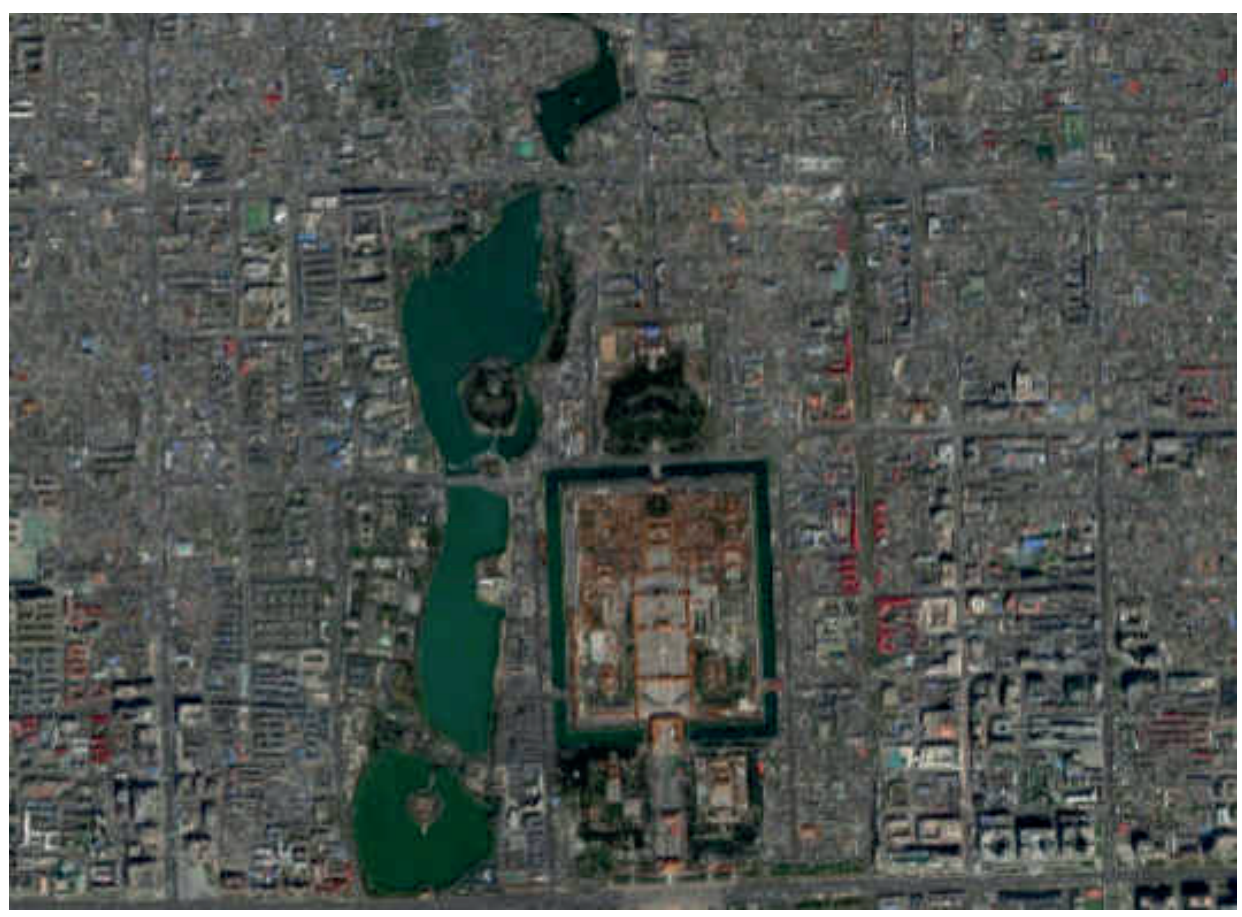

Figure 2: 'One lake, three mountains' design in Beijing's 12th-Century imperial garden, alongside the Forbidden City. The islands are: top = Penglai/Qionghua 琼华岛, middle = Yingzhou/ Tuancheng 团城, bottom = Fangzhang/Xishantai 中南海. (C) DigitalGlobe, Google, 2017) 
These imperial gardens and palaces shared what has come to be known as the 'one lake, three mountains' 一池三山 design, through which one sought to create paradise on earth, pursue immortality, and lead a heavenly existence. The 'one lake, three mountains' design remained popular for over a millennium and a half and was adopted by numerous royal garden designers. Although none of the Imperial Chinese royal gardens are extant in their original forms, remnants of the 'one lake, three mountains' design are visible in Beijing's Beihai Park 北海公园 (Figure 2), which was adapted from an imperial garden first built in 1179 CE, and in the 18th-Century Summer Palace 颐和园 in Beijing. The 'one lake, three mountains' design is also present in Xuanwu Lake 玄武湖, Nanjing. This lake had already been an imperial park for centuries prior to the construction of the Liang/Penglai, Ying/Fangzhang, and Cui/Yingzhou islands during the Song Dynasty (960-1279 CE) (Yao, 2016, p. 76).

A roughly contemporaneous adaptation of the 'one lake, three mountains' design is present in West Lake 西湖, Hangzhou. West Lake contains a number of artificial islands, including Little Yingzhou 小瀛洲, constructed in 1607. Little Yingzhou is also known as Three Pools Mirroring the Moon 三潭印月, which is in fact the name of an adjacent trio of sacred stone pagodas. Originally constructed in the 11th Century, these small stone pagodas may have acquired their holiness through their relationship to the 'one lake, three mountains' tradition and are today depicted on China’s $¥ 1$ banknote. The island and pagodas represent a major tourism site. Although Yingzhou is itself one of the three sacred islands, it is less well known in today's China than is Penglai, and it is thus that an interpretive sign on Little Yingzhou compares the landscape with that of Penglai: "The misty view of water with the reflections of the sky and clouds on its smooth surface creates a picture as mysterious as the 'Fairy Isle of Penglai', a legendary island in Chinese myths" (interpretive sign on Little Yingzhou, West Lake, seen in 2017; English original).

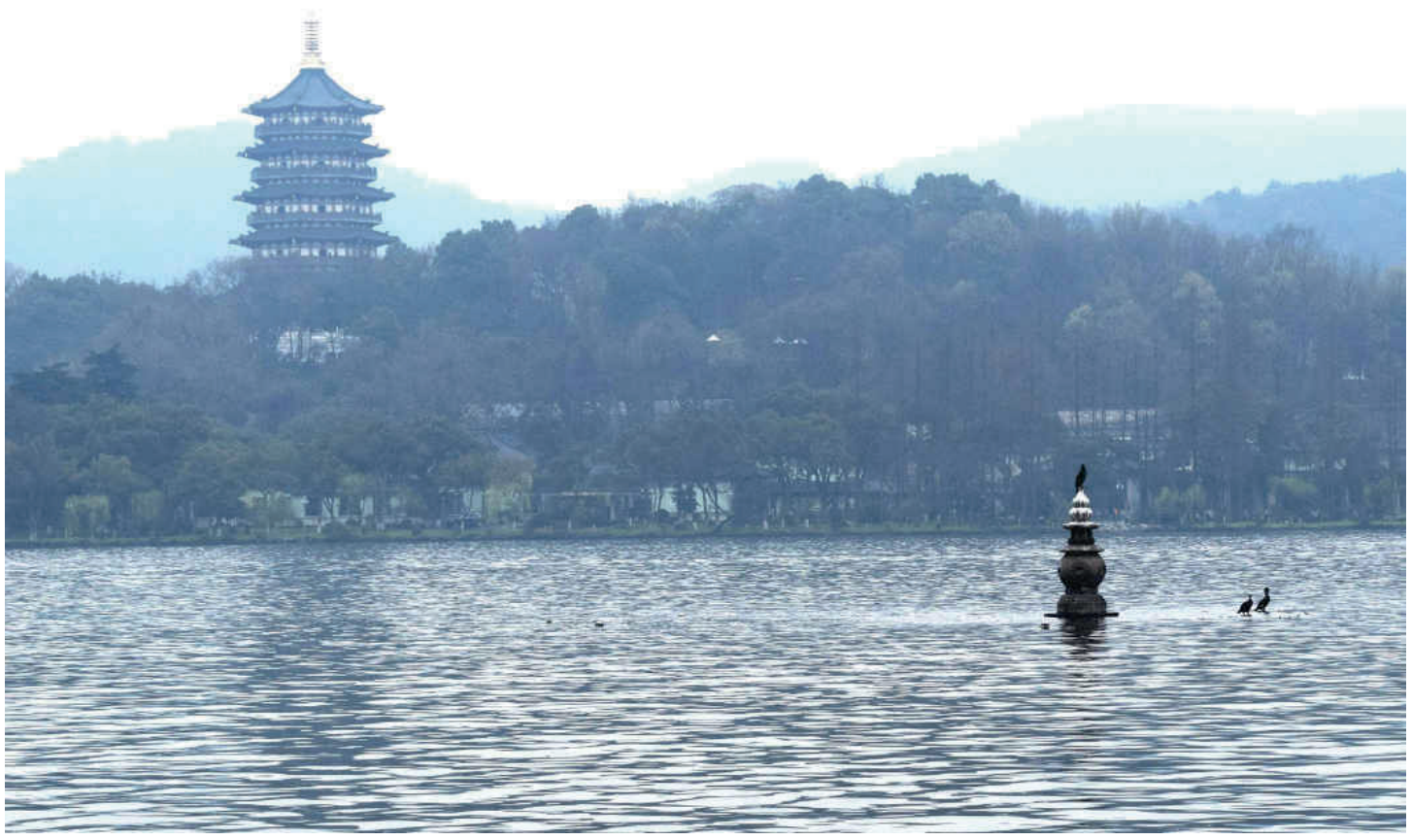

Figure 3: View out across West Lake from Little Yingzhou, with a stone pagoda of Three Pools Mirroring the Moon in the foreground. (C) Adam Grydehøj, 2017)

Imperial China was far from alone in constructing artificial islands. As Grydehøj (2015b) shows, wholly or partially artificial islands held a special association with centres of political power in Medieval and Early Modern Europe. The island form itself was sometimes regarded as possessing 
a symbolic significance, dovetailing with ideas concerning the 'ideal city' (Pigou-Dennis \& Grydehøj, 2014, p. 261). However, unlike in Medieval and Early Modern Europe, the artificial islands of Imperial China were not actually home to rulers but instead served a wholly symbolic or ritual purpose. Frequently home to monasteries, temples, or pagodas, these imitations of the three sacred islands were designed to grant power to their builders and possessors by their very presence. Indeed, in the late 3rd Century BCE, Emperor Qi Shihuang used the sacred islands at Epang Palace as sites for Taoist alchemical experimentation aimed at manufacturing elixir (Yao, 2016, p. 74). Imperial China's artificial island practices may have more in common with the sensationally symbolic artificial islands that have been constructed in Dubai, Abu Dhabi, the Australian Gold Coast, China itself, and many other locations in recent decades (e.g., Jackson \& della Dora, 2009; Gupta, 2015; Grydehøj \& Kelman, 2016a; Hayward \& Fleury, 2016) than they do with island construction in Medieval and Early Modern Europe.

\section{Other sacred islands}

Penglai, Fangzhang, and Yingzhou were not the only sacred islands in Ancient and Imperial Chinese culture. The reports of the three sacred islands in Records of the Grand Historian were drawn upon by later writers. The Classic of Mountains and Seas 山海经, a collection of mythical geography composed by multiple authors during the Warring States period (475 BCE-221 BCE), is likewise a foundational text for Chinese island thinking. It records the Chinese cultural and geographical situation prior to the Qin Dynasty as well as collects Chinese myths and legends. The book contains eight chapters of seas and one chapter of regions within the seas, which accounts for half of the work's content. Significantly, The Classic of Mountains and Seas establishes the image of the four sea gods, deities with the face of a human, the body of a bird, and snakes (of varying colours) dangling from their ears and under their feet (大荒东经, p. 208, p. 216, p. 226, p. 236). The sea god is an archetypal image in Ancient Chinese conceptions of islands and the sea: its bird body symbolises freedom of movement throughout the universe and thus the Chinese aspiration for wildness, while its snakes represent mystery, unpredictability, and darkness since snakes usually live in caves and often bring danger to the human world (李文钰, 2007).

The islands of The Classic of Mountains and Seas includes various states. There are countries of winged inhabitants, giants, tiny people, women, men, immortals, long arms, and so on. The Classic of Mountains and Seas produced a set of influential island narrative patterns, which can be categorised into 1) 'god island topic', 2) 'mermaid topic', and 3) 'state of giants topic' or 'monster topic' (倪浓水, 2009). Later writers set their stories on similar islands, which in a sense embody the Chinese imagination of the outside world. Ni (倪浓水, 2009) discusses the impacts of these three narrative patterns, for example how the 'god island topic' influenced a series of stories concerning gods living on islands described in The Classic of Mountains and Seas. These works include Zhuangzi's A Happy Excursion (庄子. 逍遥游), Liezi's Lieguye Mountain (列子. 列姑射山), and two stories in Pu Songling's Strange Stories from a Chinese Studio (蒲松龄. 聊斋志异).

Records of Ten Islands within the Sea 海内十洲记 from the Weijin (220-420 CE) and Southern and Northern Dynasties (420-589 CE) is another important Chinese work concerning islands and the ocean. Although the book was purportedly written by Dongfang Shuo 东方朔, this authorship has been widely disputed (李剑国, 1984, pp. 167-171; 李丰柕, 1986, p. 144). Records of Ten Islands within the Sea describes the eponymous ten islands, which are scattered throughout the four seas. This book's importance lies in its further elaboration upon the legendary three sacred islands of the early Qin Dynasty, which it blends with the Han Dynasty tradition of ten states, thereby merging mythologies and systematising the so-called 'ten states, three islands' 十洲三岛 concept (王庆云, 1999). The ten states一Zuzhou 祖洲, Yingzhou 瀛洲, Xuanzhou 玄洲, Yanzhou 炎洲, Changzhou 长洲, Yuanzhou 元洲, Liuzhou 流洲, Shengzhou 生洲, 
Fenglinzhou 凤麟洲, and Jukuzhou 聚窟洲—are large islands located far out in the ocean and are home to treasure, immortals, and elixir.

Other Imperial Chinese geographical or historical literature concerning islands include Zhanghua's Records of Diverse Matters (张华. 博物志), Wang Jia's Records of Miscellaneous Matters (王嘉. 拾遗记), and some stories in Liu Xiang's Biography of the Gods and Goddesses (刘向. 列仙传). Most island stories in these books deploy narrative patterns set by The Classic of Mountains and Seas.

During the Weijin and Southern and Northern Dynasties, the 'ten states, three islands' narrative entered Taoism. The quest for immortality and manufacturing of elixir were significant aspects of Taoist philosophy, and because islands were said to be home to immortals, they became important sites within the Taoist spiritual system. The 3rd- and 4th-Century CE Taoist monk Ge Hong 葛洪 sets forth three hierarchical categories of immortals and 'sacred places'仙境:

The upper class who become immortals will become officials in the court of Heaven; the middle class who become immortals will gather and reside in Kunlun; and the lower class who become immortals will live in the human world (王明, 1980, p. 76).

Although Kunlun 昆仑 is one of the islands described in Records of Ten Islands within the Sea, in Ge Hong's account, Kunlun serves as a general term for sacred islands. The belief that immortals live on islands prompted numerous real-life Taoist journeys in search of elixir and islands of immortality, reinvigorating the tradition for sacred island quests that had flourished centuries before, in the Qin and early Han Dynasties. Records of Ten Islands within the Sea describes the appearance of the sacred islands and gives detailed descriptions of their locations, life of immortality, elixir, and other characteristics (李茙, 2012). Ever since, it has been popular within Chinese literature to use islands as settings for stories about searches for immortality and encounters with immortals. So straightforward is this association that Journey to the West 西游记, a 16th-Century classic of Chinese literature, lists "all the Immortals of the Ten Islands" alongside the various major Buddhist and Taoist deities and spirits who are invited to a heavenly banquet (Wu, 1942, p. 62).

During the Tang Dynasty (618-907 CE), as well as the Five Dynasties and Ten Kingdoms periods (907-960 CE), poetry was the most popular literary form. It is thus interesting that most narratives concerning islands and seas were contained in prose stories and novels, most of which follow the narrative patterns set by The Classic of Mountains and Seas and concern:

1) gods, goddesses, and immortals living on various islands (e.g., Stories of Sequential Gods 续仙传, A Random Collection of Youyang 酉阳杂组, Records of Possible Gods 疑仙传);

2) treasures on islands ('The Big Crab in the South Sea' 南海大蟹 and 'Gods with a Merciful Heart' 慈心仙人 from Records of General Supernaturals 广异记; ‘The Stamp of the Gold Turtle' 金龟印, 'The Prince of Japan', and 'Yuancangij' from A Random Collection of Duyang 杜阳杂篇);

3) monsters, immortality, and supernatural beings in the sea or on islands (e.g., stories in Records of General Supernaturals 广异记 and A Collection of Supernaturals 集异记).

For all of the above stories, see 李时人编校 (1998).

Alongside this tradition, the four sea gods described in The Classic of Mountains and Seas were passed down to the Tang Dynasty, becoming integrated into Chinese Buddhist faith as rain or weather gods in the form of 'Dragon Kings' 龙王. In Mahāvaipulya Buddhāvatamsaka Sūtra 大方广佛华严经, the dragon kings are described as follows:

There are several dragon kings with compassion, benevolence, and mercy, namely Biloubocha Dragon King, Suojieluo Dragon King, Yunyinmiaozhuang Dragon King, Yankouhaiguang Dragon King [...] They dedicate themselves to arranging clouds and rainfall so as to prevent humans from suffering from heat (实叉难陀, 1996, p. 5). 
The dragon king tradition dates back to the Northern Wei Dynasty (386-534 CE), and its rise parallels the increasing popularity of Buddhism in China (周晓薇, 2005). Ultimately, the ten dragon kings of Buddhist tradition were reduced to four dragon kings of the East, West, North, and South, conceptually merging with the four island-dwelling sea gods from The Classic of Mountains and Seas. In Chinese, they are usually referred to as Dragon Kings of Four Seas 四海龙王. During the reign of Tang Xuanzong 唐玄宗 (685-762 CE), the four sea gods were conferred the title of wang 王 (Lord), as recorded in the late 8th-Century work Tongdian 通典:

In January of the Tenth Year of Tianbao rule [i.e., $751 \mathrm{CE}]$, the sea god of East Sea was conferred the title of Lord of General Virtue, the god of South Sea Lord of General Interest, the god of West Sea Lord of General Nourishment, and the god of North Sea Lord of General Nurturing (杜佑, 1988, p. 859).

The four dragon kings were expected to show mercy and bring good fortune to the human world, and the titles granted to them demonstrate the localisation of Buddhist deities (who had originated in the Indian subcontinent) through their merger with the Chinese four sea gods. It subsequently became popular to worship and build temples for the four, island-dwelling dragon kings.

In his 8th-Century poem 'Tianmu Mountain Ascended in a Dream’ 梦游天姥吟留别, Li Bai 李白 says, “A seafaring visitor will talk about Yingzhou Island, which waters and mists conceal beyond approach” (海客谈瀛洲, 烟涛微茫信难求). This expresses traditional Chinese conceptions of islands up until the Qing Dynasty (1644-1911). The image of sacred islands had been part of the Chinese worldview since at least the earliest era of Chinese civilization from which there are extant written sources. Chinese culture treated islands as distant, exotic, inaccessible homes to spirits and immortals. The early history of sacred island quests was later incorporated into Taoist practice in the search for immorality and elixir, and the narrative patterns developed in the Ancient Chinese Classic of Mountains and Seas came to dominate Imperial Chinese stories of islands and the ocean.

When considering these literary and architectural elaborations upon island kingdoms and fairylands, it is interesting to reflect upon island studies theories regarding relationality and assemblages (e.g., Stratford et al., 2011; Pugh, 2013, 2016; Hayward, 2012a, 2012b). The symbolism and metaphorical power of this multitude of sacred Chinese islands were somehow linked to their interrelatedness, not just with the mainland but also with one another. Though Penglai was the most sought-after sacred islands, it was evidently insufficient to simply construct an imitation of Penglai in one's palace garden; instead, it was the joint construction of Penglai, Fangzhang, and Yingzhou within a body of water that proved symbolically productive. The Chinese paradise was an archipelago, not a single, more-or-less symmetrical island like More's Utopia or Medieval and Early Modern Europe's ideal island cities (cf. Pigou-Dennis \& Grydehøj, 2014).

Similarly, the practical impossibility of successfully attaining immortality by means of seeking out or creating sacred islands in Ancient and Imperial China means that the movement between mainland and island as well as between island and island must have taken on primary symbolic importance. In some cases, as we shall see, reaching or successfully constructing the island itself could ultimately result in a monastic or hermetic life as an island resident, in the transition from mainlander to islander, which would possess a spiritual meaning of its own.

The Chinese association between islandness (or archipelagacity) and sacredness persists. Putuoshan 普陀山, an island in the Zhoushan archipelago, is one of China's four Buddhist sacred mountains, is said to be the dwelling place of the bodhisattva Guanyin (Figure 4), and has been a pilgrimage site for many centuries. Putuoshan possibly gained prominence over competing religious sites precisely because of its location on maritime shipping routes (Bingenheimer, 2016, pp. 3-4), highlighting how the symbolic isolation and conceptual simplicity of islands can coexist with a tendency toward economic openness and cultural contact. Putuoshan is today home to numerous monasteries and temples and is a major destination for domestic religious tourism. 


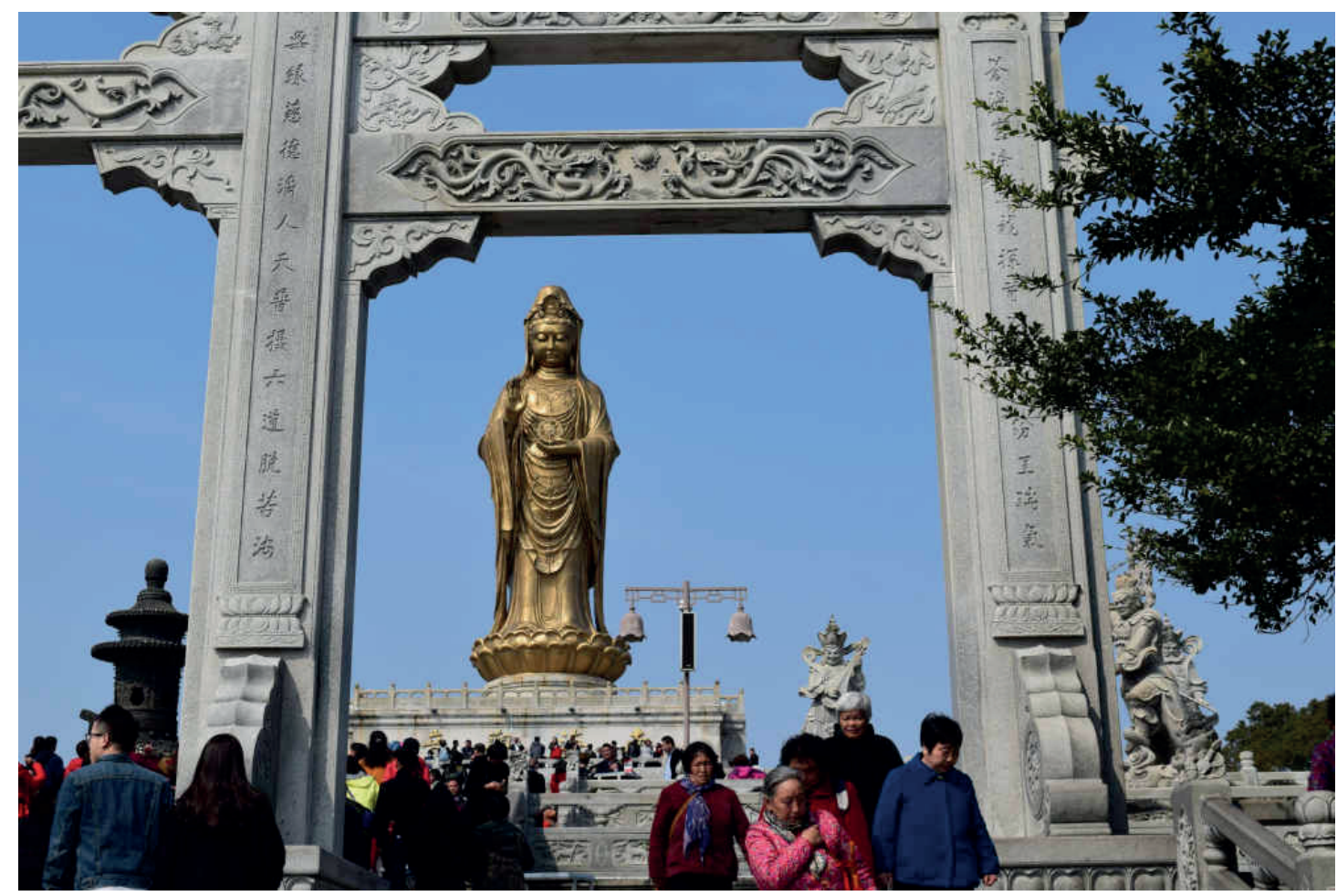

Figure 4: Religious tourism on Putuoshan, China. (C) Adam Grydehøj, 2017)

\section{Comparison with Western sacred islands}

Like Chinese culture, Western culture has a tradition of regarding islands as sacred and of locating legendary lands on islands. The Celtic cultures of Britain and Ireland alone, for example, producedor were later said to have produced-a litany of mystical islands, including Avalon (resting place of King Arthur); Gwales (home to the loquacious head of the hero Bendigeidfran/Brân the Blessed and his companions); any number of otherworlds and fairylands (Caer Siddi, Emain Ablach, Tír na nÓg, Mag Mell); Hy Brasil (a mystical, inaccessible, mist-cloaked island of purported Irish tradition); Falias, Findias, Gorias, and Murias (the islands from which Ireland's mythical Tuatha Dé Danann brought their four great treasures); and the various islands visited on the voyages of Bran mac Febail and St Brendan (Kincaid, 2007; Mackley, 2008; Freitag, 2013).

Celtic traditions were influenced by narratives from the Classical Greek and Roman cultures. The Greek hero Odysseus famously encountered mystical islands on his long journey back from Troy to his island kingdom of Ithaca, including the island of the Lotus-Eaters; the island of the cyclops Polyphemus; the floating island of Aeolia; the island of the giant cannibalistic Laestrygonians; Aeaea, the island of the sorceress Circe; the island of the Sirens; the wandering rocks of Planctae (which Odysseus wisely avoids); Thrinakia, home to the cattle of the sun god Helios; Ogygia, the island of the sorceress Calypso; and Scheria, the magical island of the Phaeacians. We may also note the lost kingdoms of Panchaea and Atlantis as well as the heavenly Elysium/Fortunate Isles/Isles of the Blessed.

Furthermore, Europe had hosted traditions of an elixir of immortality since the Middle Ages. Pre-existing legends connected with Alexander the Great, the mythical king Prester John, Marco Polo, and other figures entered into early 16th-Century narratives concerning the contemporary Spanish conquistador Ponce de Léon, who has subsequently been associated with a quest for an island-based fountain of youth (Peck, 1998).

Such was not merely the stuff of legend, however, for offshore islands in Western Europe became popular sites for religious retreat and sacred journeys. Monasteries were established on many small islands in the Middle Ages and Early Modern period, with examples including Caldey 
and Bardsey in Wales, Skellig Michael and Innisfallen in Ireland, Lindisfarne and Tresco in England, Iona and Inchcolm in Scotland, Mont Sant-Michel and Île Saint-Honorat in France, Gaztelugatxe and Isla de la Cartuja in Spain, Reichenau and Herreninsel in Germany, and Solovetsky and Valaam in Russia. Such religious institutions often arose as a result of initial settlement by hermits and religious recluses. As we have seen, islands have sacred associations in Chinese tradition, but it is particularly significant in this context to note that, within the concept of xianshan 仙山 ('heavenly mountain'), the Chinese xian 仙 can refer to not only gods, spirits, fairies, and immortals but also to hermits and skilled Taoist fangshi 方士 (alchemists/sorcerers).

Despite their divergent essential associations (with mountains in China and with water in Europe), islands had similar effects on the Ancient and Imperial Chinese, as well as the Classical, Medieval, and Early Modern European imaginations. They were regarded as mystical places, homes to gods, spirits, sorcerers, monsters, monstrous races, and paradisiacal otherworlds. Most Western writers have not, however, been aware of Chinese traditions concerning islands, and analyses as to why European culture tends to regard islands as special have suffered as a result. Take, for instance, Gillis (2007, p. 281), one of the most insightful of Western island theorists, who states:

In the Middle Ages Europe's mythical geography moved decisively offshore. Medieval island romanticism, followed by the Renaissance revival of classical insular mythology, seeded the Atlantic with all kinds of wondrous isles, which lured Europeans westward during the Age of Discovery. It may seem incongruous that, at the very moment the horizons of space and time were expanding rapidly toward infinity, islands should so preoccupy educated Europeans. Yet it was precisely the vast new expanses of empty space and incalculable time that called forth early modern islomania. As long as continental landmasses were incomprehensible, represented as great voids on world maps and lacking chapters in world histories, islands remained the most easily grasped and most frequently described topographic feature. Put quite simply, islands were good to think with at a time when other landforms had not yet acquired their own mythical geographies. The myths and narratives of continents would emerge in due course, but initially it was islands that allowed Europeans to organize mentally as well as economically and politically their newly found seaborne empires.

Gillis's argument sounds convincing when viewed from a European perspective alone, but it loses its glamour when Chinese traditions are taken into account. After all, the cultural context of Ancient and Imperial China was otherwise quite different from that of Medieval Europe. Whereas China's centres of political, cultural, and religious power usually lay deep in the continental interior, those of Europe mostly near the coast. Chinese rulers, politicians, poets, and religious figures may have known little of islands and the sea, but this was not true in Europe.

By the same token, though Europeans may have regarded continental landmasses as "incomprehensible, represented as great voids on world maps" (Gillis, 2007, p. 281), in contrast to clearly delimited islands, the opposite was the case for the contemporary Chinese. We thus see a marked difference between the relative accuracy of terrestrial and maritime maps in Medieval Europe and Imperial China: Europe possessed a sense of and skill in charting maritime spatiality long before it developed comparable detail in terrestrial maps (Steinberg, 2005; Tolias, 2013) whereas Chinese maps (e.g., Figure 5) included detailed continental interiors long before they grappled successfully with the spatial relationships of places separated by water.

It thus seems that the cultural significance of islands for mainlanders thus is not significantly influenced by personal familiarity with islands. Gillis (2007, p. 277) says of European culture that "At times it was continents that were remote and isolated, the outposts of islands. Up to the end of the eighteenth century insularity was associated with mainlands, not islands." We cannot say the same for Ancient and Imperial Chinese culture, yet both civilisations developed strikingly similar sacred island geographies. 


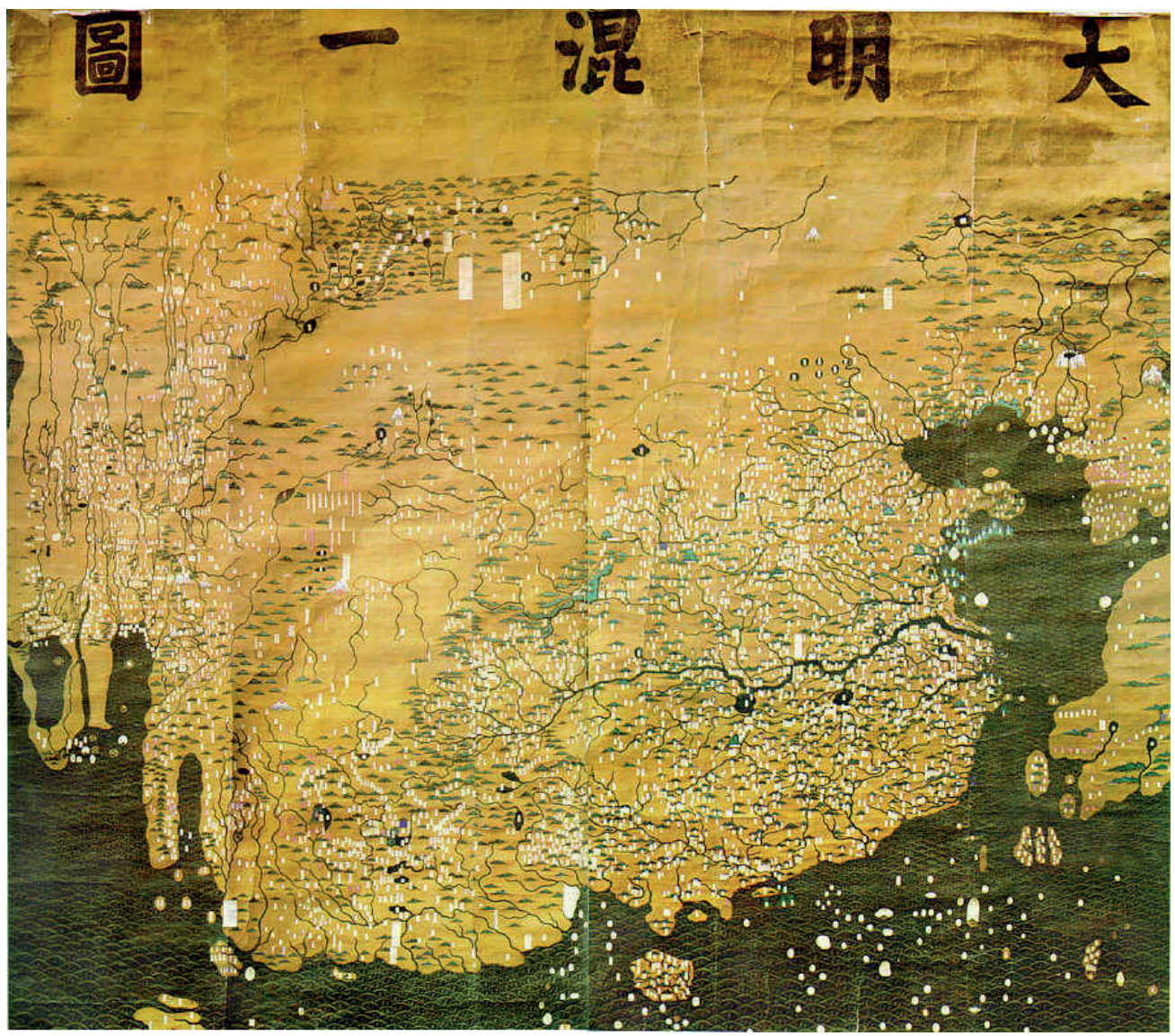

Figure 5: The Great Amalgamated Map 大明混一图, c. 1390 CE, includes far more detail of China's continental interior than of adjacent maritime spaces. (Source: Wikimedia Commons, https://commons.wikimedia.org/wiki/File:Da-ming-hun-yi-tu.jpg)

\section{Islands of adventure in the age of exploration}

Bearing in mind the above, it is no surprise to see that works of fiction and other literature involving islands in later periods of Imperial China bear resemblances to later Western island literature.

From around the start of the second millennium CE, China's shipping industry underwent rapid development, and China became a maritime power. Two maritime shipping routes are recorded in 'Records of Geography' in the mid-11th Century New Book of Tang 新唐书. One route started from Guangzhou in the Pearl River Delta and led to Southeast Asia, the Middle East, and East Africa. The other route started from Dengzhou 登州 (today's Penglai, Shandong Province) and led to the Bohai Sea and Korea (欧阳修、宋祈, 2003, pp. 1147-53). The increase in maritime activities generated stories about pirates. One example is Lu Qiu's 'A Maritime Businessman' (卢求. 贩海客), which tells the story of a wealthy businessman who stops to rest on an island and is murdered by other businessmen. Another story is Niu Su's 'Li Yong' (牛肃. 李坙), in which the mayor Li Yong abuses his power and acts like a pirate, robbing a cargo ship and murdering the sailors onboard. There are also many Tang Dynasty stories about dangers and accidents on islands and the sea. Wang Du's 'A Story of the Old Mirror' (王度. 古镜记) describes the dangers of big tides. Zhaoziqin's 'Zhang Jiongcang' and 'Cui Yuanzong'(赵自勤. 张圆藏. 崔元综) as well as Lu Giu's 'Kang Zhongqi' (卢求. 康仲戚) describe how strong winds can endanger ships and sailors. (For the above stories, see 李时人编校, 1998.) Such themes were further developed in stories from the Song Dynasty (960-1234 CE) and Yuan Dynasty (1271-1368 CE). 
Song and Yuan Dynasty writings on islands inherited narratives from the Tang Dynasty as well as of the Five Dynasties and Five Kingdoms period, focusing on immortals, supernatural beings, monsters, treasure, danger, and accidents (see e.g. 洪迈, 1981; 徐钋, 1996; 刘斧, 1983). Both the Northern Song and Southern Song Dynasties were under threat from foreign invasions, which inspired stories about maritime battles. Many war stories concern the campaign that Li Bao 李宝 waged on the west of Jiaozhou Peninsula against the Liao regime; the War in Yashan 崖山 that Zhang Shijie 张世杰 waged against the Yuan army; and the Yuan's battle against Japan. These wars were recorded in history books but also adapted into fiction. For example, the Li Bao-led attack on the island of Tangdao 唐岛 to the west of Jiaozhou Peninsula was recorded in the History of Song Dynasty 宋史 as well as adapted into stories collected in Royal Stuff of the Rising Period 中兴御物录 and Records inside and outside the Court since Jianyan 建炎以来的朝野杂记.

In 1405, Zheng He 郑和 led China's first expedition to the Western Oceans 西洋, later leading six more multiyear expeditions as well as voyages within the Malay Archipelago (Selin, 2008). Sponsored by the Ming Emperor, Zheng He reached as far as the Arabian Peninsula and East Africa, yet his voyages, facilitated by rapid developments in maritime technologystopped in 1433, when China began its long, slow turn inward. In 1523, the Ming Court suspended all maritime activities, originally as a result of pirate activities and threats from Japan and other neighbouring countries. This 'closed-door policy' 闭关锁国政策 was extended by the Qing Emperors (徐明德, 1995), largely isolating the Chinese from the outside world prior to the First Opium War (1839).

The great ocean voyages had little impact on Chinese perspectives on islands and the world. Most Chinese maritime stories remained static and involved traditional narrative patterns, topics, and forms. Stories about islands feature, for example, in Pu Songling's Qing Dynasty Strange Stories from a Chinese Studio (蒲松龄. 聊斋志异) and Li Ruzhen's Flowers in the Mirror (李汝珍. 镜花缘).

Much of this literature predates comparable Western European fictional narratives inasmuch as the novel and short story genres, which had undergone uninterrupted development since Ancient China, were only rediscovered or revived in Western Europe in the 17th Century (with Classical Greek and Roman literature, Chivalric Romances, Old Norse sagas, and other literary predecessors having primarily thematic rather than formal influence on the emerging genres). It is thus that works such as William Shakespeare's The Tempest (1611) and Daniel Defoe's Robinson Crusoe (1719) and Captain Singleton (1720) introduced to Western literature island motifs (pirates, shipwreck, cannibals, betrayal) that had been present in Chinese fiction for centuries. Yet maritime and island fiction has possessed a cultural significance in Europe from the 1600s onward (Le Juez \& Springer, 2015; Riquet, 2016; Kinane, 2016; Crane \& Fletcher, 2016) that comparable fiction in contemporary China lacked. Tellingly, Shen (2016) credits early 20th-Century translations of Robinson Crusoe and the book's subsequent popularity in China with sparking a maritime spirit in the Chinese that had been lost during the centuries of isolation under the closed-door policy.

\section{Islands of exile}

In the Imperial Chinese imagination, islands were not just sacred places; they were also places of exile. From the Tang Dynasty onward, officials who fell out of favour with the emperor were frequently demoted from positions in the central court and assigned to serve on remote islands: isolated from the mainland, far from the centre of power, with very limited transport options, and with difficult natural environments.

Penglai, for example, is the most famous of the sacred islands in Ancient and Imperial Chinese literature, yet it is also a real county in today's Shandong Province 山东省, which includes a number of small islands. Shamen Island 沙门岛—in today's Changshan archipelago, Changdao County, northwest Penglai-was a place of exile for demoted officials in the Song and Yuan Dynasties. The History of Song Dynasty 宋史 records that “The criminals were usually sent to Shamen Island. Most died upon arrival” (脱脱等, 1975, p. 5017). Exiles were not provided with their basic needs, 
and agricultural land on the islands was scarce, with the result that many out-of-favour officials perished during their periods away from court. Despite its sacred reputation and symbolism, the government regarded the actual Penglai as a barren wasteland, suitable only for criminals.

In the extreme south of China, even farther from the centre of political power, Yazhou 崖州—today's Sanya in the island province of Hainan—was also a popular place of exile. Among the prominent officials demoted and exiled to Yazhou during the Tang and Song Dynasties was the famous poet Su Shi 苏轻. Ironically, Su Shi, who lived in exile on Hainan in the 1090s, had decades earlier been responsible for constructing elements of the sacred artificial island landscape architecture of West Lake in Hangzhou.

Islands have long been associated with places of exile and imprisonment in Western culture as well. Australia, itself formerly an enormous island prison colony of the United Kingdom, possessed numerous offshore prison islands (Gillis, 2007, p. 215). Emperor Napoleon of France was made a political exile on the island of Elba, then following his escape and return to power, was exiled to St Helena in the South Atlantic. More recently, Kim Jong-nam took self-imposed political exile from North Korea in China's autonomous island city of Macau (Chosunilbo, 2010). Islands have been home to many of the world's most infamous prisons and places of exile, including Coiba (Panama); Robben Island (South Africa); Sado Island (Japan); Devil's Island (French Guiana); Île Sainte-Marguerite (France); Jeju (South Korea); Galápagos Islands (Ecuador); Andaman Islands (India); Alcatraz, Blackwell's Island, Rikers Island, and Fort Jefferson/Garden Key (USA).

Island prisons are not just a thing of the past: England continues to use its two largest off-shore islands as prison sites: three on the Isle of Sheppey (Elmley, Standford Hill, and Swaleside) and two on the Isle of Wight (Albany and Parkhurst, and formerly Camp Hill, which closed in 2013). States increasingly use remote islands as offshore spaces in which to confine migrants and asylum seekers, for instance Australia's use of detention centres on Manus Island, Nauru, and Christmas Island (Fraenkel, 2016; Mountz, 2017) and the various Mediterranean island detention centres (Bernardie-Tahir \& Schmoll, 2014; Loyd \& Mountz, 2014; Dines et al., 2015). The USA, meanwhile, continues to use its Guantánamo Bay enclave on Cuba as a detention centre for a particular class of jurisdictionally and politically problematic prisoners (Reid-Henry, 2007).

\section{Analysis}

Islands have long played an important role in the Chinese worldview. In Ancient and Imperial China, islands were associated with sacred or heavenly realms, abodes of gods and spirits, and the possibility of immortality. This interacted with Taoist and emergent Buddhist traditions as well as fed into palace garden landscape architecture, which sought to imitate sacred island landscapes and spatialities. As Chinese maritime activities increased, Chinese island narratives came to include elements of adventure. Yet, alongside these mystical and fictional representations, islands were being used as places of exile for demoted court officials.

This dual conception of islands as simultaneously heavenly and hellish may be less paradoxical than it first appears. Key to both conceptions is the notion of relative inaccessibility and difficult mobility. Both Chinese and Western traditions emphasise that otherworldly paradise is difficult to reach. If Chinese and European islands were associated with monks and hermits, it was precisely because islands were ideal sites for solitude and seclusion. The life of a hermit may have been regarded as sacred and may in some cases have ultimately given rise to wealthy monastic institutions, but it initially implied harsh living conditions and isolation from worldly comforts.

Remote island holiness and magical ability are linked with solitary suffering, a condition that differs little whether occasioned by political exile or voluntary reclusiveness. It was while in exile on Patmos that St John envisioned the Apocalypse, resulting in the biblical Book of Revelations (Lowenthal, 2007, p. 203), and the Mountain of Purgatory in Dante's Divine Comedy is an island up which souls must struggle toward Paradise. This suggests a further link between islands and mountains in Chinese culture, with both landforms being associated with hermits and holy sites. 
More broadly, David Lowenthal (2007) argues that a variety of positive and negative island stereotypes have common roots in the sense of islands being places apart. Remoteness and separateness can encourage associations with romantic seclusion or parochialism, with vibrant adventure or with being trapped, with hardy self-sufficiency or with vulnerability to disaster, with tourist paradise or with impoverished backwater (see also Baldacchino, 2008; Baldacchino, 2012a; Vannini, 2011; Grydehøj \& Kelman, 2016b; Clarke \& Johnston, 2016). It is precisely the boundedness of island place-and perhaps the assembly of discrete island places within archipelagic space-that makes islands special in particular but related ways to different peoples.

As far as the striking similarities between Chinese and European island traditions go, it may be significant that, at the times when these traditions were undergoing their most active development, both China and Europe were emerging as empires, with wide political and cultural reach. Differences between Chinese and European conceptions of statehood and territoriality (Grydehøj, 2015a, p. 432) notwithstanding, the conceptual placement of both the holy and the horrific beyond the periphery of the empire may say something about the geographic visions that emanate from centres of power. Further comparative research into non-Western and non-imperial conceptions of islands would, however, be necessary to clarify this potential relationship.

It is necessary to bear in mind that both mainland European and mainland Chinese literary and symbolic understandings of islands coexisted with actual island communities for whom islands were 'home'. Besides being simultaneously a paradisiacal otherworld and a hellish spot for depositing exiles, Changshan/Penglai was also a place where islanders lived out their lives. Hainan, for its part, had been home to a variety of distinct cultures and ethnic groups prior to its falling under the political control of China's dominant Han culture. In Ancient and Imperial China, it was precisely because islands were so distant from mainland centres of power that it was possible for social, political, and religious actors to ignore 'real' islands and indulge in idealised island abstractions, at the same time as demoted court officials were being sent into island exile-quite concretely 'out of sight, out of mind'. Even today, Putuoshan's reputation as a holy site attracts large numbers of pilgrims, which in turn fuels a tourism industry that not only provides livelihoods for a great many monks, taxi drivers, salespeople, etc., on Putuoshan itself but that also helps support the economy of the Zhoushan archipelago as a whole. Mainland representations, metaphors, and understandings of islands interact in a complex manner with islands themselves.

\section{Conclusion}

This paper has provided an overview of conceptions of islands in Ancient and Imperial China, as well as some rather basic comparisons with Western traditions. Even on this superficial level, however, marked similarities emerge between Ancient and Imperial Chinese representations of islands on the one hand and Classical, Medieval, and Early Modern European representations of islands on the other. These similarities call into question some of the previously asserted and specifically Western explanations for what makes islands so alluring. As such, further efforts to consider the significance of islands in non-Western cultures can perhaps inform our broader understanding of the continuing island 'lure' (Baldacchino, 2012b), as well as the continuing representation of islands as places of both leisure and risk, heaven and hell, mobility and confinement. It seems clear in any case that it is not just the mainland that casts particular dreams upon islands but also islands that exert particular influences on the mainland imagination.

A truly decolonial island studies must go beyond simply considering 'local' reactions to island metaphors imposed by the West. It must transcend efforts to adapt Western thoughts to non-Western contexts. Instead, it must consider alternative island and archipelagic epistemologies that predated, have existed alongside, or arose in spite of imperialism and colonial processes. The present paper has served as an example of how studies that take an explicitly non-Western and decolonial perspective may change our way of considering islandness as a global phenomenon. 


\section{Acknowledgments}

We wish to thank Jonathan Pugh and Ian Michael Philip Kinane for commenting on a draft of this paper.

\section{References (English)}

Baldacchino, G. (2012a). Islands and despots. Commonwealth \& Comparative Politics, 50(1), 103-120. https://doi.org/10.1080/14662043.2012.642119

Baldacchino, G. (2012b). The lure of the island: a spatial analysis of power relations. Journal of Marine and Island Cultures, 1(2), 55-62. https://doi.org/10.1016/j.imic.2012.11.003

Baldacchino, G. (2008). Studying islands: on whose terms? Some epistemological and methodological challenges to the pursuit of island studies. Island Studies Journal, 3(1), 37-56.

Baldacchino, G. (2004). The coming of age of island studies. Tijdschrift voor economische en sociale geografie, 95(3), 272-283. https://doi.org/10.1111/j.1467-9663.2004.00307.x

Bernardie-Tahir, N., \& Schmoll, C. (2014). The uses of islands in the production of the southern European migration border. Island Studies Journal, 9(1), 3-6.

Bingenheimer, M. (2016). Island of Guanyin: Mount Putuo and Its Gazetteers. New York, NY: Oxford University Press. https://doi.org/10.1093/acprof:oso/9780190456191.001.0001

Casagrande, M. (2016). Heritage, tourism, and demography in the island city of Venice: depopulation and heritagisation. Urban Island Studies, 2, 121-141. https://doi.org/10.20958/uis.2016.6

Chosunilbo (2010) Where is Kim Jung-il's eldest son? Chosunilbo. 04 October. Available at: http://english.chosun.com/site/data/html dir/2010/10/04/2010100401059.html

Clarke, R., \& Johnston, A. (2016). Travelling the sequestered Isle: Tasmania as penitentiary, laboratory and sanctuary. Studies in Travel Writing, 20(1), 1-16. https://doi.org/10.1080/13645145.2015.1136091

Crane, R., \& Fletcher, L. (2016). The genre of islands: popular fiction and performative geographies. Island Studies Journal, 11(2), 637-650.

Dines, N., Montagna, N., \& Ruggiero, V. (2015). Thinking Lampedusa: border construction, the spectacle of bare life and the productivity of migrants. Ethnic and Racial Studies, 38(3), 430-445. https://doi.org/10.1080/01419870.2014.936892

Fletcher, L. (2011). ' '... some distance to go': a critical survey of Island Studies. New Literatures Review, 47-48, 17-34.

Fraenkel, J. (2016). Australia's detention centres on Manus Island and Nauru: an end of constructive Pacific engagement? The Journal of Pacific History, 51(3), 278-285. https://doi.org/10.1080/00223344.2016.1233802

Freitag, B. (2013). Hy Brasil: the metamorphosis of an island: from cartographic error to Celtic Elysium. Leiden \& Boston: Brill.

Gegeo, D.W. (2001). Cultural rupture and indigeneity: the challenge of (re)visioning 'place' in the Pacific. The Contemporary Pacific, 13(2), 491-507. https://doi.org/10.1353/cp.2001.0052

Gillis, J.R. (2007). Island sojourns. Geographical Review, 97(2), 274-287. https://doi.org/10.1111/j.1931-0846.2007.tb00403.x

Grydehøj, A. (2017). A future of island studies. Island Studies Journal, 12(1), 3-16. https://doi.org/10.24043/isj.1

Grydehøj, A. (2015a). Island city formation and urban island studies. Area, 47(4), 429-435. https://doi.org/10.1111/area.12207

Grydehøj, A. (2015b). Making ground, losing space: land reclamation and urban public space in island cities. Urban Island Studies, 1, 96-117. https://doi.org/10.20958/uis.2015.6 
Grydehøj, A., \& Kelman, I. (2016a). Island smart eco-cities: innovation, secessionary enclaves, and the selling of sustainability. Urban Island Studies, 2(1), 1-24. https://doi.org/10.20958/uis.2016.1

Grydehøj, A., \& Kelman, I. (2016b). The eco-island trap: climate change mitigation and conspicuous sustainability. Area, 49, 106-113. https://doi.org/10.1111/area.12300

Gupta, P. (2015). Futures, fakes and discourses of the gigantic and miniature in 'The World' islands, Dubai. Island Studies Journal, 10(2), 181-196.

Hau'ofa, E. (1994). Our sea of islands. The Contemporary Pacific, 6(1), 147-161.

Hay, P. (2006). A phenomenology of islands. Island Studies Journal, 8(2), 209-232.

Hayward, P. (2012a). Aquapelagos and aquapelagic assemblages. Shima, 6(1), 1-11.

Hayward, P. (2012b). The constitution of assemblages and the aquapelagality of Haida Gwaii. Shima, 6, 1-14.

Hayward, P., \& Fleury, C. (2016). Absolute waterfrontage: road networked artificial islands and finger island canal estates on Australia's Gold Coast. Urban Island Studies, 2, 25-49. https://doi.org/10.20958/uis.2016.2

Hong, G. (2017). Locating Zhuhai between land and sea: a relational production of Zhuhai, China as an island city. Island Studies Journal, 12(2), forthcoming. https://doi.org/10.24043/isj.16

Jackson, M., \& della Dora, V. (2009). 'Dreams so big only the sea can hold them': man-made islands as anxious spaces, cultural icons, and travelling visions. Environment and Planning $A$, 41(9), 2086-2104. https://doi.org/10.1068/a41237

Kinane, I. (2016). Theorising literary islands: the island trope in contemporary Robinsonade narratives. London \& New York: Rowman \& Littlefield.

Kincaid, P. (2007). Islomania? insularity? the myth of the island in British science fiction. Extrapolation, 48(3), 462-471. https://doi.org/10.3828/extr.2007.48.3.5

Le Juez, B., \& Springer, O. (Eds.) (2015). Shipwreck and island motifs in literature and the arts. Leiden: Brill.

Lowenthal, D. (2007). Islands, lovers, and others. Geographical Review, 97(2), 202-229. https://doi.org/10.1111/j.1931-0846.2007.tb00399.x

Loyd, J. M., \& Mountz, A. (2014). Managing migration, scaling sovereignty on islands. Island Studies Journal, 9(1), 23-42.

Mackley, J.S. (2008). The legend of St. Brendan: a comparative study of the Latin and Anglo-Norman versions. Leiden \& Boston: Brill. https://doi.org/10.1163/ej.9789004166622.i-352

Mignolo, W.D. (2011). The darker side of Western Modernity. Durham NC \& London: Duke University Press. https://doi.org/10.1215/9780822394501

Mountz, A. (2017). Island detention: Affective eruption as trauma's disruption. Emotion, Space and Society, forthcoming. https://doi.org/10.1016/j.emospa.2017.02.006

Nadarajah, Y., \& Grydehøj, A. (2016). Island studies as a decolonial project. Island Studies Journal, 11(2), 437-446.

Peck, D. T. (1998). Misconceptions and myths related to the 'Fountain of Youth' and Juan Ponce de Leon's 1513 exploration voyage. New World Explorers (December), 1-22.

Pigou-Dennis, E., \& Grydehøj, A. (2014). Accidental and ideal island cities: islanding processes and urban design in Belize City and the urban archipelagos of Europe. Island Studies Journal, 9(2), 259-276.

Pugh, J. (2016). The relational turn in island geographies: bringing together island, sea and ship relations and the case of the Landship. Social \& Cultural Geography, 17(8), 1040-1059. https://doi.org/10.1080/14649365.2016.1147064

Pugh, J. (2013). Island movements: thinking with the archipelago. Island Studies Journal, 8(1), 9-24.

Reid, H.S. (2007). Exceptional sovereignty? Guantánamo Bay and the re-colonial present. Antipode, 39(4), 627-648. https://doi.org/10.1111/j.1467-8330.2007.00544.x 
Riquet, J. (2016). Islands erased by snow and ice: approaching the spatial philosophy of cold water island imaginaries. Island Studies Journal, 11(1), 145-161.

Ronström, O. (2013). Finding their place: islands as locus and focus. Cultural Geographies, 20(2), 153-165. https://doi.org/10.1177/14744744012445446

Ronström, O. (2009). Island words, island worlds: the origins and meanings of words for 'islands' in north-west Europe. Island Studies Journal, 4(2), 163-182.

Selin, H. (Ed.) (2008). Encyclopedia of the history of science, technology, and medicine in non-Western cultures. Amherst, MA: Springer. https://doi.org/10.1007/978-1-4020-4425-0

Shen, Q. (2016). Robinson Crusoe's translation and spreading of marine spirit in pre-modern China. Journal of Marine and Island Cultures, 5(1), 1-4. https://doi.org/10.1016/j.imic.2016.04.001

Steinberg, P.E. (2005). Insularity, sovereignty and statehood: the representation of islands on portolan charts and the construction of the territorial state. Geografiska Annaler: Series B, Human Geography, 87(4), 253-265. https://doi.org/10.1111/j.0435-3684.2005.00197.x

Steyn, G. (2015). The impacts of islandness on the urbanism and architecture of Mombasa. Urban Island Studies, 1, 55-80. https://doi.org/10.20958/uis.2015.4

Stratford, E., Baldacchino, G., McMahon, E., Farbotko, C., \& Harwood, A. (2011). Envisioning the archipelago. Island Studies Journal, 6(2), 113-130.

$\mathrm{Su}, \mathrm{P}$. (2017). The floating community of Muslims in the island city of Guangzhou. Island Studies Journal, 12(2), forthcoming. https://doi.org/10.24043/isj.18

Swaminathan, R. (2015). Ports and digital ports: the narrative construction and social imaginaries of the island city of Mumbai. Urban Island Studies, 1, 35-54. https://doi.org/10.20958/uis.2015.3

Teaiwa, T. (2006). On analogies: rethinking the Pacific in a global context. The Contemporary Pacific, 18(1), 71-87. https://doi.org/10.1353/cp.2005.0105

Tolias, G. (2013). The politics of the isolario: maritime cosmography and overseas expansion during the Renaissance. The Historical Review/La Revue Historique, 9, 27-52. https://doi.org/10.12681/hr.287

Tuan, Y.F. (1974). Topophilia: a study of environmental perception, attitudes, and values. Englewood Cliffs, NJ: Prentice-Hall.

Vannini, P. (2011). Constellations of ferry (im)mobility: islandness as the performance and politics of insulation and isolation. Cultural Geographies, 18(2), 249-271. https://doi.org/10.1177/1474474010397597

Wu, C.E. (1942) Monkey. A. Waley (Trans.). London: Penguin.

Yao, Y. (2016). Nanjing: Historical landscape and its planning from geographical perspective. Singapore: Springer. https://doi.org/10.1007/978-981-10-1637-0

\section{References (Chinese)}

曹先擢, 苏培成. 汉字形义分析字典 [D]. 北京：北京大学出版社， 1999.

杜佑. 通典 [M]. 王文锦点校. 北京：中华书局, 1988 .

顾炎武. 历代宅京记 [M]. 北京: 中华书局, 1984 .

洪迈. 夷坚志 $[\mathrm{M}]$. 北京：中华书局，1981.

李丰柕. 六朝隋唐仙道类小说研究 [M]. 台北: 台湾学生书局, 1986.

李剑国. 唐前志怪小说史 [M]. 天津: 南开大学出版社, 1984 .

李晟. 道教信仰中的地上仙境体系 [J]. 宗教学研究. 2012(2)：33-38

李时人编校、何满子审定. 全唐五代小说 $[\mathrm{M}]$ 。西安：陕西人民出版社，1998.

李文钰. 《山海经》的海与海神神话研究 [J]. 政大中文学报, 2007 (7) : 1-24.

孟天运. 蓬莱仙话传统与历代帝王寻仙活动 $[J]$. 东方论坛，2002(2)：19-22. 
倪浓水. 中国古代海洋小说的逻辑起点和原型 $[J]$. 中国海洋大学学报（社会科学版） 2009 (1) : 10-15.

欧阳修、宋祁．新唐书 [M]。北京：中华书局, 2003.

实叉难陀译. 大方广佛华严经 [M] . 台北: 财团法人佛陀教育基金会出版部, 1996.

司马光. 资治通鉴 (卷180隋记四) [M]. 北京: 中华书局, 1976.

司马迁．史记 [M]．北京：中华书局, 1959 .

脱脱等. 宋史 $[M]$. (卷199)。北京: 中华书局, 1975 .

王明. 抱朴子内篇校释 [M]。 中华书局, 1980 .

王庆云. 中国古代海洋文学历史发展的轨迹 $[J]$. 青岛海洋大学学学报. 1999 (4)： $70-77$.

徐明德．论十四至十九世纪中国的闭关锁国政策 [J]。海交史研究. 1995 (1)：19-37.

周明初校注．山海经 [M]。杭州：浙江古籍出版社，2002.

周晓薇. 古代典籍中的龙王及其文化寓意 $[J]$. 陕西师范大学学报 (哲学社会科学版). 2005, 34 (3) : 87-94. 